\title{
Analysis Of The Level Of Understanding Concepts And Critical Thinking Ability Of Students In Resolving Trigonomic Equations Using Graphs
}

\author{
Maulida Luka Yusrina, Siti Inganah, Octavina Rizky Utami Putri \\ Department of Mathematics Education, Faculty of Teacher Training and Education, \\ University of Muhammadiyah Malang \\ maulidaluka.yusrina@gmail.com
}

\begin{abstract}
This research aims to describe the level of understanding the concept and critical thinking in resolving trigonometric equations using graphs. Tests and interviews were conducted to search for data and study more in the ability to understand the concepts and critical thinking skills that students have in resolving trigonometric equations using graphs. The test given to the students is a test of the explanation with the subject of his research is a class XI student. The subject selection of six students is based on the category of ability and daily replay value of the student in trigonometric materials. The six students are each - two students of high, medium and low categories. The results showed that the ability level of understanding students ' concepts in determining the set of solving trigonomic equations using graphs, gained students understanding the concept of high and moderate levels. Students with a high level of understanding are able to fulfill all indicators - an indicator of concept comprehension. Students with the level of understanding of concepts are also meeting the indicators of understanding the concept but less appropriate, which has not been able to identify the properties of a concept. Students are also less able to classify objects based on the requirements that make up the concept. The level of students ' critical thinking ability to determine the set of solving trigonomic equations using graphs obtained by the subject of students critical thinking moderate and low levels. Students with critical thinking levels are not yet able to meet interpretation indicators, i.e. students have not been able to understand and write the answer to the problem given. Students with critical thinking levels are also underprivileged to meet critical indicators of inference. Students with critical thinking levels are less able to draw conclusions, i.e. less capable of providing the right reasons for student work. Students with critical thinking levels are low, not yet capable of meeting critical thinking indicators in determining the set solving trigonometric equations using graphs. Students have not been able to meet all indicators of critical thinking ability.
\end{abstract}

Keywords: Ability; concepts; critical thinking ; trigonometry

\section{INTRODUCTION}

One of the main objectives of mathematics learning in school is to develop the ability to understand the concept of students (Setyaningrum, Hendikawati, \& Nugroho, 2018). Concept understanding needs to be taught to students since the student sits on elementary school, students are required to understand the definition and understanding and how to properly solve the problem or operate the math, because it To study mathematics at a higher level (Herawati, Siroj, \& Basir, 2010). Understanding the concept of a person who has the ability to understand and master something well and can apply and restructure the knowledge that develops based on the concept understood (Alamsyah, 
2017). Meanwhile, according to Fadzillah (2016) understanding of concept is the ability of a person to master a concept that is learned and able to reexpress a concept with language that is easy to understand, so students can be said to have understood a Concept when students are able to rereveal the concepts that have been taught and students can provide examples and non examples of the concept. Julaiha (2011) states that concept comprehension is the ability to derive the meaning of an abstract idea that can be used or allows one to classify or classify a particular occurrence or object.

Mathematics is one of the subjects that must exist since elementary school education and is able to form a systematic, logical, creative, and critical mindset (Fatmawati, Mardiyana, \& Triyanto, 2014). Students are strongly required to have a higher thought ability in resolving the problem solving in mathematics (Mahmuzah, 2015). Mathematics subjects are very helpful in improving the thinking of students, therefore the role of mathematics lessons in improving the ability of critical thought is very important (Rahayuningsih \& Kristiawan, 2018). Turmuzi (2017) stated that critical thinking ability is crucial for the creation of the quantity and quality of the succeeding generations that can compete globally. According to Ennis (in Reza, 2016) that critical thinking is a sensible and reflective thought that focuses on deciding what to believe or do. The ability of critical thinking is a high-level thinking capability consisting of important elements such as interpreting, analyzing, evaluating, and making a decision to solve problems (Shanti, Sholihah, \& Martyanti, 2017).

Based on Permendikbud year 2016, number 24, mathematical trigonomic material studied since class X SMA in the first semester even compulsory mathematics then continued through interest mathematics in class XI and XII SMA. Trigonometry is one of the important material that students must learn (Subroto \& Sholihah, 2018). Huljannah, Sugita, \& Anggraini (2015) said that often encountered some students who have difficulty while conducting learning in the classroom are included in trigonometric material which is why it is incomprehension students on mathematical concepts. It is similar to the results of Pradana's research (2016) on understanding the concept of students still not fully embedded in the students. Actually students already understand the intent of the problem, but the students have not mastered the counting operation. In addition to the Fithriyah research, Sa'dijah, \& Siswara (2016) concluded that students of class IX-D SMPN 17 Malang have low critical thinking skills. It is demonstrated by the test results of students ' critical thinking ability. Therefore, this research aims to, describe the level of understanding the concept and critical thinking of students in solving trigonometric equations using graphs.

\section{RESEARCH METHODS}

The type of research used is qualitative descriptive research. Data used in the form of test result data and interviews. The subject of this study amounted to 6 students with the ability to understand the concept and critical thinking of 2 high categories, 2 medium categories, and 2 low categories. The subject is selected based on daily ability and replay value in trigonometric materials. The instruments used in this study are instrument sheet tests and interview sheets. Data collection techniques (1) A description test on trigonometric materials specifies the set of completion using a graph of description (2) interviews to explore data related to understanding the concept and the ability of critical thinking in resolving the equation Using trigonometry graphs. The data analysis technique used is (1) data reduction, which data has been obtained categorized by the level of 
understanding the concept and critical thinking ability of students in solving trigonometric equations using high IE chart, Medium, or Low (2) presentation of data, presenting information that has been obtained from the results of the explanation and interview ability of the concept and critical thinking students to obtain results and conclusions (3) the withdrawal of conclusions, analyzing how The results of the test descriptions and interviews so that can be drawn conclusions how the level of understanding the concept and the ability of critical thinking students in solving trigonomteri equations using graphs.

The indicator of the concept of understanding used in this study is (1) identifying the properties of a concept (2) restating the concepts that have been studied (3) classifying the objects based on the presence of the requirements that make up The concept (4) applies the concept logically. The indicator of the critical thinking ability used in research is (1) interpretation is to understand by writing down the answers of the problems given (2) the analysis is to identify the relationship between problems with the concept. (3) Evaluation is using appropriate strategy in the problem solving given (4) inference is drawing conclusions correctly.

\section{RESULTS AND DISCUSSION}

Based on the test results and interviews obtained from six students, the highest and lowest score is 35 and 14. The score you acquired can be categorized by category understanding students ' concepts. The results of the research gained from six students are two highcategory students, and four students with a category are being to understand the concept of students in solving trigonometric equations using graphs.

Table 3. List of acquired names, scores, and categories

\begin{tabular}{lll}
\hline Name & Skor & Concept comprehension Category \\
\hline S1 & 35 & High \\
S2 & 30 & High \\
S3 & 22 & Medium \\
S4 & 21 & Medium \\
S5 & 19 & Medium \\
S6 & 14 & Medium \\
\hline
\end{tabular}

Understanding the concept of high category, students are able to identify the properties of a concept, able to re-declare the concept that has been studied, able to classify objects based on the requirements that make up the concept, and able to apply the concept logically in resolving trigonometric equations using graphs. Understanding the concept of medium category, students are less able to identify the properties of a concept, less able to redeclare concepts that have been studied, are less able to classify objects based on the presence of the requirements form the concept, and are less able to apply concepts logically in resolving trigonometric equations using graphs. The following is the result of several students with high and medium category.

1. High Understanding of Student concept Category

The result of the number 1 :

$$
y_{1}=\tan x, y_{2}=\sqrt{3} \text { di selang waktu } \frac{[0,2 \pi] \rightarrow \frac{7 \pi: 180^{\circ}}{2 \pi: 2.180^{\circ}=360^{\circ}}}{2}
$$

Figure 1. Result of work for the first indicator of the number 1 
The subject is capable of meeting the indicators of understanding the first concept of being able to identify the properties of a concept of trigonometric equations by changing the interval from radians to form degrees. It is only in the writing of equal signs (=) of the subject writing like a sign of division (:). When the interview session turns the subject admitted in working about too quickly so that in writing the equals sign (=) such as the division sign (:) When the subject's intent is to write the equals $\operatorname{sign}(=)$.

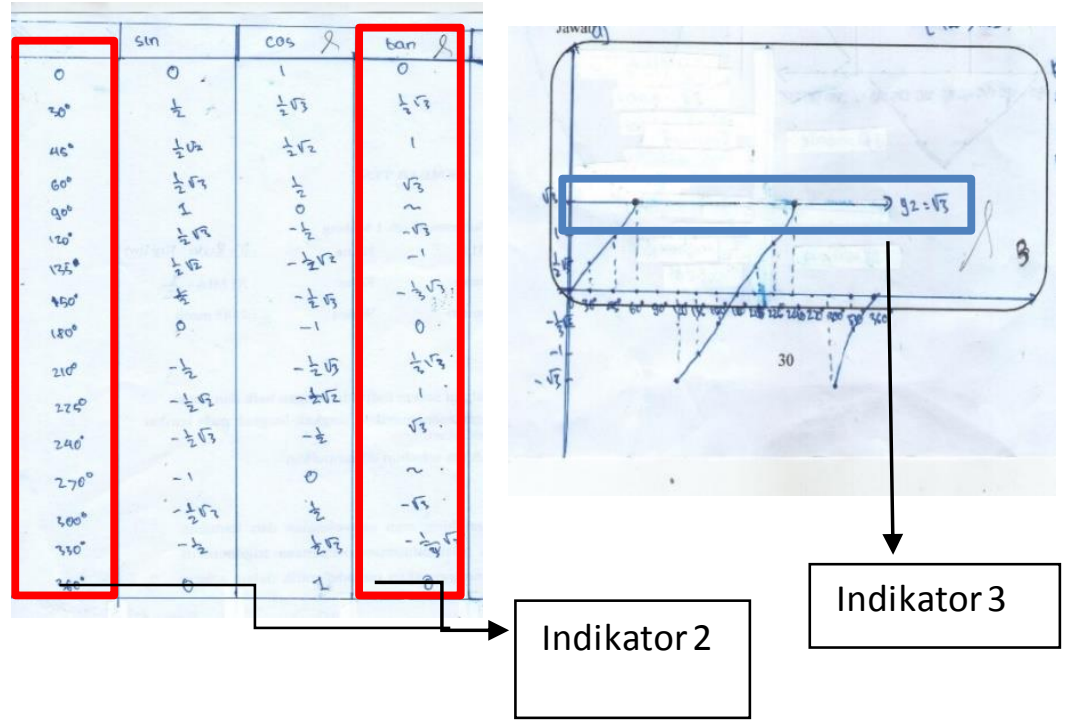

Figure 2. Results of the second and third indicators of the number 1

In the second indicator the subject is able to meet an indicator where the subject is able to redeclare the concept that has been studied, by writing a Help table before drawing the known graph on the matter. In the third indicator the subject is also capable of fulfilling the indicator where the subject is able to classify the objects - objects based on the requirements that make up a concept, by sliding the $\mathrm{x}$ axis so far $y_{2}=\sqrt{3}$ as in Figure 2 above.

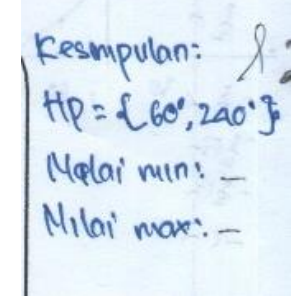

Figure 3. The result of work for the fourth indicator of the number 1

Based on the results and interviews, the subject is able to meet the indicator of understanding the fourth concept of being able to make conclusions based on concepts that have been studied, the subject is able to declare the value of completion The minimum questions asked in the question. When the subject interview session is also able to explain the conclusion appropriately, and able to explain if the trigonometric equations $y=\tan x$ has no maximum and minimum values, only on the subject answer sheet is not written in full. The subject only writes with the (-) sign that the subject is not there. 
The result of the number 2 :

$$
\begin{aligned}
& y_{1}=3 \cos (-2 x), y_{2}=1,5 \text { di selang waktu }[0,2 \pi]+\pi \tau: 180^{\circ}, 124 \\
& 2 \pi: 2.180^{\circ}=366^{\circ}
\end{aligned}
$$

Figure 4. Result of work for the first indicator of the number 2

Subjects are less capable of meeting indicators of understanding the first concept that is less able to identify the properties of a concept of trigonometric equations. The subject fault can be seen in Figure 4, the answer written in the subject is actually correct but in the process of calculating the subject is less thorough. On the answer sheet the subject answered $2 \times 180=36$. During the interview session, the subject recognizes that in the work of the matter, the subject is rushed so that the subject is less thorough in the calculation process.

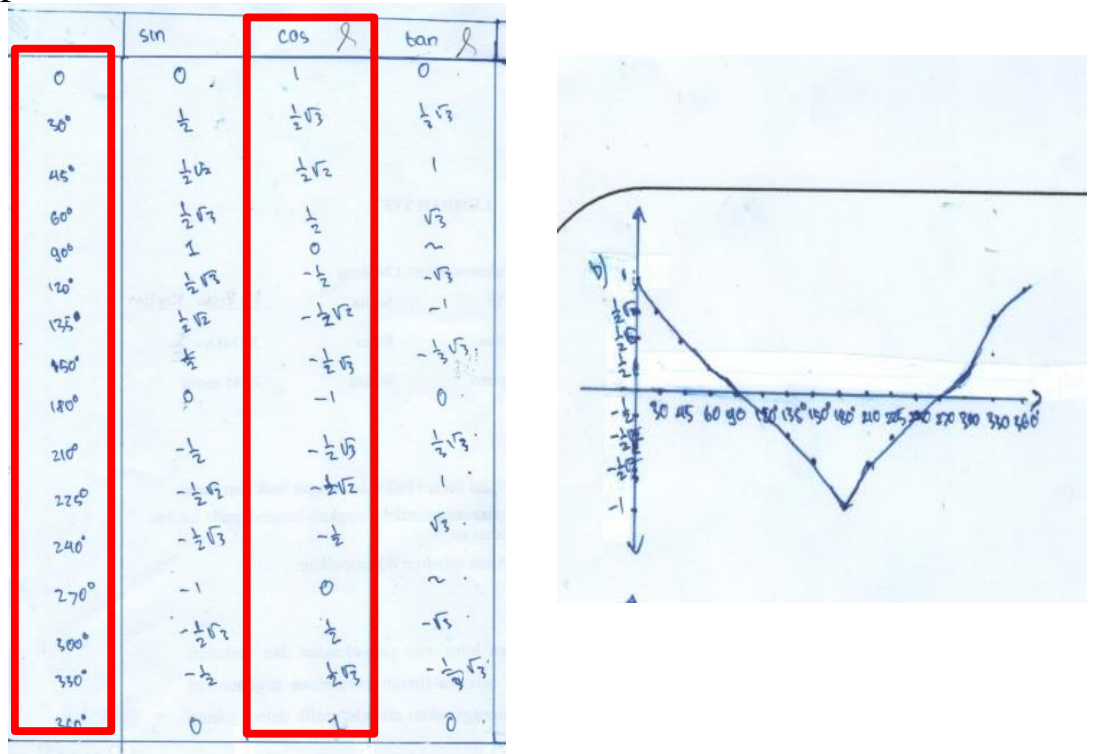

Figure 5. The result of the second indicator of the number 2

In the second indicator the subject is able to meet an indicator where the subject is able to redeclare the concept that has been studied, by writing a Help table before drawing the known graph on the matter.

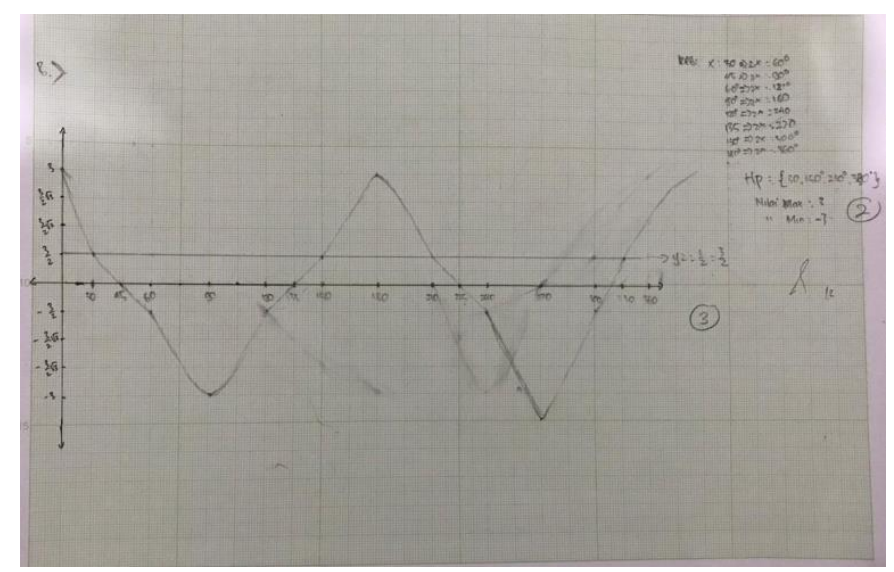

Figure 6. The result of work for the third indicator of the number 2 
In the third indicator the subject is also able to fulfill the indicator where the subject is able to classify the objects - objects based on the requirements that make up a concept, by sliding the $\mathrm{x}$ axis so far $y_{2}=\frac{3}{2}$ as in Figure 6 above.

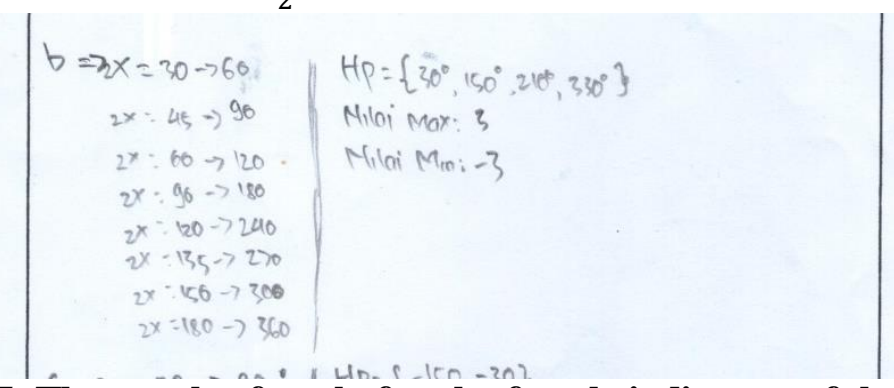

Figure 7. The result of work for the fourth indicator of the number 2

Based on the results and interviews, the subject is able to meet the indicator of understanding the fourth concept of being able to make conclusions based on concepts that have been studied, the subject is able to declare the value of completion The minimum questions asked in the question. When the subject interview session is also able to explain the conclusions appropriately.

The result of the number 3 :

$$
y_{1}=-2 \sin (3 x), y_{2}=-1 \text { di selang waktu }[-\pi, \pi]
$$

Figure 8. Result of work for the first indicator of the number 3

Based on the results of the work and interviews the subject is able to meet the indicators of understanding the first concept of being able to identify the properties of the concept of trigonometric equations by changing the hose/interval from the form of radians to degrees. When a subject's interview session is able to explain the answer.

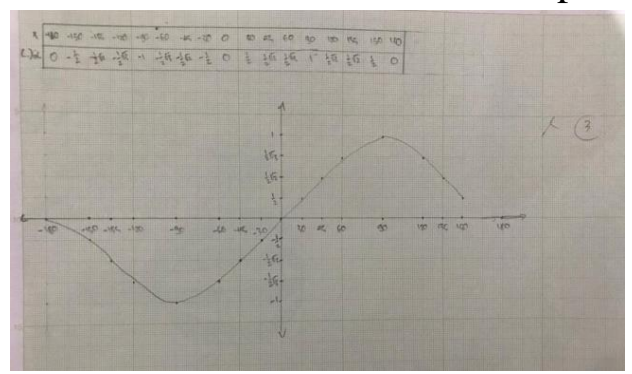

Figure 9. The result of the second indicator of the number 3

In the second indicator the subject is able to meet an indicator where the subject is able to redeclare the concept that has been studied, by writing a Help table before drawing the known graph on the matter.

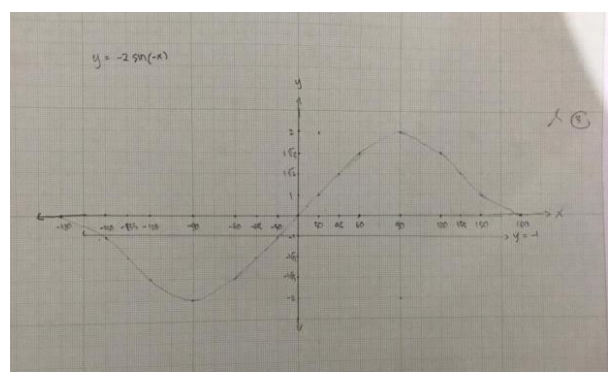

Figure 10. The result of work for the third indicator of the number 3 
In the third indicator the subject is also able to fulfill the indicator where the subject is able to classify the objects - objects based on the requirements that make up a concept, by sliding the $\mathrm{x}$ axis so far $y_{2}=-1$ as in Figure 10 above.

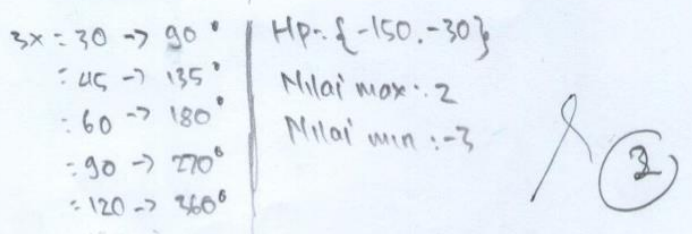

Figure 11. The result of work for the fourth indicator of the number 3

Based on the results and interviews, the subject is able to meet the indicator of understanding the fourth concept of being able to make conclusions based on concepts that have been studied, the subject is able to declare the value of completion The minimum questions asked in the question. When a subject interview session is also able to explain conclusions appropriately.

Understanding the concept of high category is able to fulfill all indicators understanding concepts. However, in this study there are several indicators that are less fulfilled by the subject, the indicator identifies the nature of a concept. This is a student with a high concept understanding capable of fulfilling three of the four indicators understanding the concepts that exist in the study. This is in line with the research of Dawn, Kodirun \& Arapu (2017) students with the ability of understanding the concept of high category can master six of the seven indicators of understanding student concept.

2. Medium tudent Concept Understanding

The result of the number 1

$$
y_{1}=\tan x, y_{2}=\sqrt{3} \text { di selang waktu }[0,2 \pi]=2 \times 180=360^{\circ}
$$

Figure 12. Result of work for the first indicator of the number 1

Subjects have not been able to meet the indicators of understanding the first concept that is not yet able to identify the properties of a trigonometric equation. The subject has not shown changes in the hose/interval from radians to form degrees. In the subject's answer, arrive - suddenly the subject performs a calculation like Figure 12 above. During the interview session, the subject claimed only to follow the answer of the friendfriend's subject which was 180 times, hence the subject wrote the answer as in Figure 12 above.

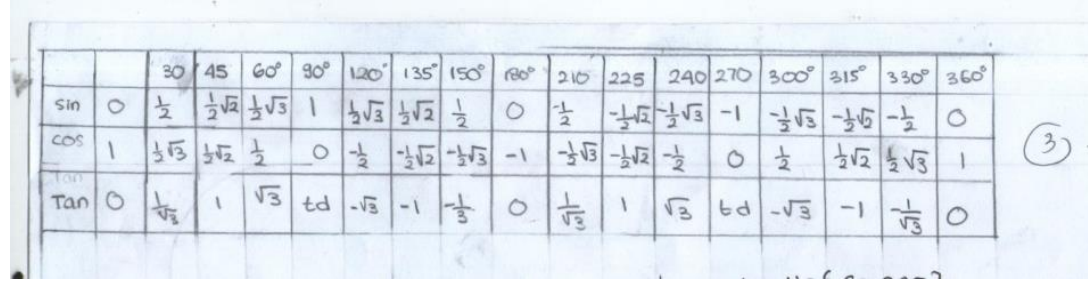




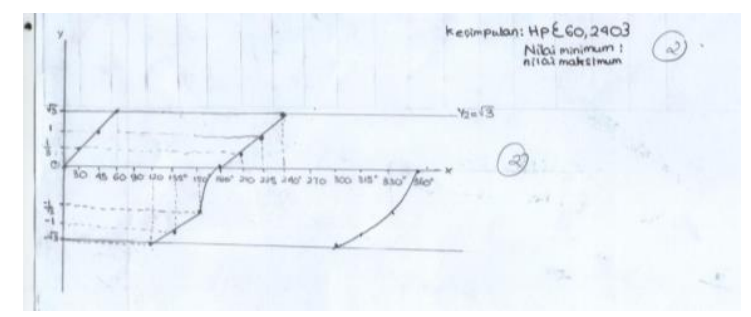

Figure 13. The result of the second indicator of the number 1

On the second indicator the subject is able to meet an indicator where the subject is able to redeclare the concept that has been studied, before drawing the subject graph write the Help table to draw the chart.

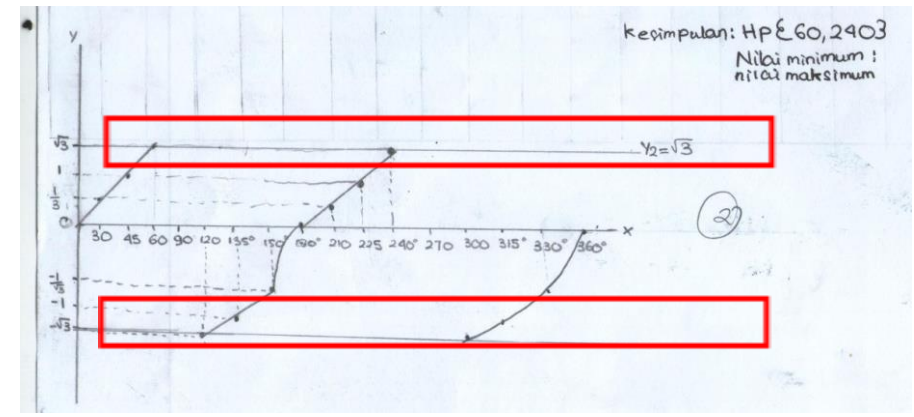

Figure 14. The result of work for the third indicator of the number 1

On the third indicator the subject is less capable of meeting the indicator where the subject is less able to classify the objects - objects based on the requirements that constitute a concept. Should the subject only need to shift the $x$ axis as far as $y_{2}=\sqrt{3}$ Just don't have to shift the $x$ axis as far as $y_{2}=-\sqrt{3}$ too. During the interview session, the subject S3 admitted that the subject was slightly forgotten how to determine the set of trigonometric equation completions using graphs. Subject only remember to shift the $x$ axis so far $y$, but forget if only needed is to shift the $x$ axis as far as it is known in the problem.

$$
\begin{array}{r}
\text { kesimpulan: } H p\{60,2403 \\
\text { Nilai minimum: } \\
\text { nilai maksimum }
\end{array}
$$

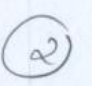

Figure 15. The result of work for the fourth indicator of the number 1

In the fourth indicator the subject is less capable of meeting the indicators of understanding the concept is less capable of making conclusions based on concepts that have been studied. The subject fault can be seen in Figure 15, the value of solving trigonometric equations written by the subject is correct, but the subject forgot to write the maximum value and the minimum value asked in the question. How to write curly braces/ \{\} The subject is also less precise. During the interview session, the subject claimed to not yet know the maximum value and minimum value of trigonometric equations $y=$ $\tan x$ and the subject also explained that during this time if creating curly braces as in Figure 15 above.

The result of the number 2 : 


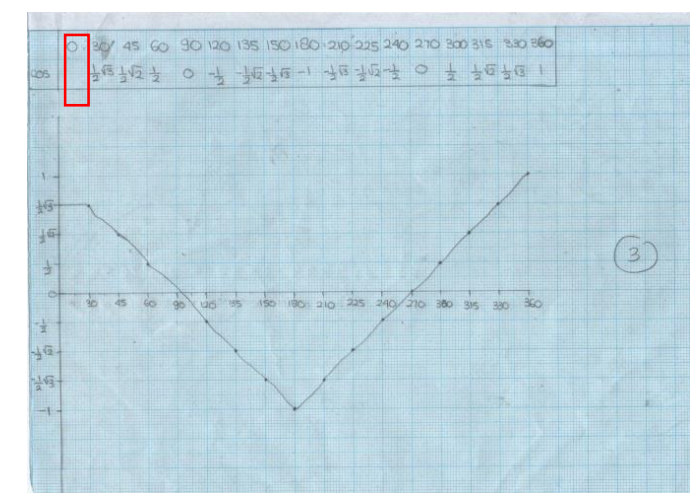

Figure 16. The result of the second indicator of the number 2

On the second indicator the subject is less capable of meeting the indicator where the subject is less able to redeclare the concept that has been studied. The subject's working step before drawing a chart is to write the first aid table correctly, but in the Help table in Figure 16 not all values are met. The Cos value of 0 in the table above is still empty or no reply from the subject. When interviewed the subject admitted that the actual subject understands the Cos value of 0 but because the work is rush-hurry the subject forget to reexamine the results of his work and there are steps missed.

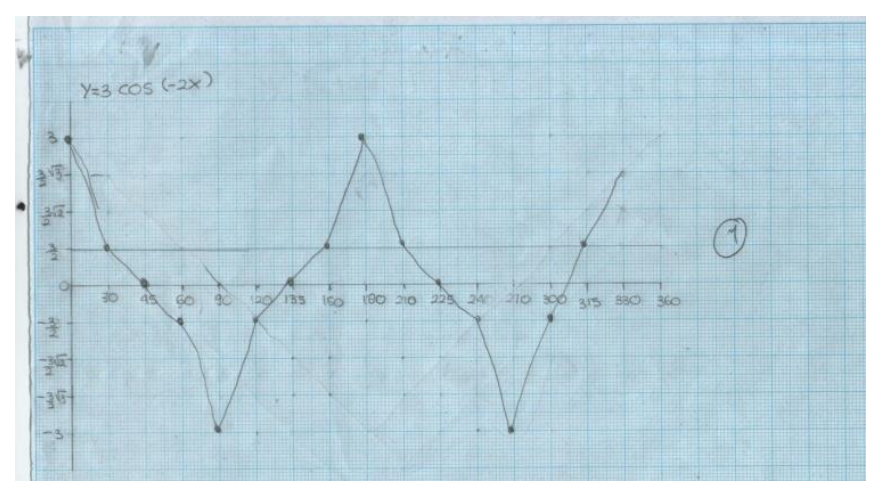

Figure 17. The result of work for the third indicator of the number 2

On the third indicator the subject has not been able to meet the indicator where the subject has not been able to classify objects - objects based on the requirements that constitute the concept. The subject error can be seen in Figure 17, the subject can only draw the chart but not yet able to shift the $x$ axis as far as the $y$ value is known in question and yet be able to find the cut point. During the interview session, the subject admitted still confused over the working step of determining the set solving trigonometric equations using graphs.

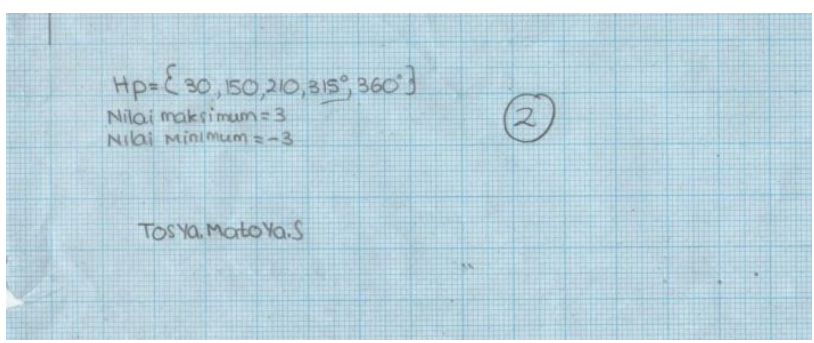

Figure 18. The result of work for the fourth indicator of the number 2

In the fourth indicator, the subject is less capable of meeting the indicators of understanding the concept is less capable of making conclusions based on concepts that have been studied. The answer to the subject is actually correct, but there is a value set of settlement that is still less precise. The correct settlement set value is $H P=$ 
$\left\{30^{\circ}, 150^{\circ}, 210^{\circ}, 330^{\circ}\right\}$, but the subject writes the set of completion $\left\{30^{\circ}, 150^{\circ}, 210^{\circ}, 315^{\circ}, 360^{\circ}\right\}$. During the interview session, the subject admitted still confused over the working step of determining the set solving trigonometric equations using graphs. The subject is accustomed to determining the set solving trigonometric equations using algebraic means.

The result of the number 3:

The subject has not been able to meet the first indicator of concept understanding, which is not yet able to identify traits of trigonometric equations. The subject does not change the time lapse from radians to form degrees

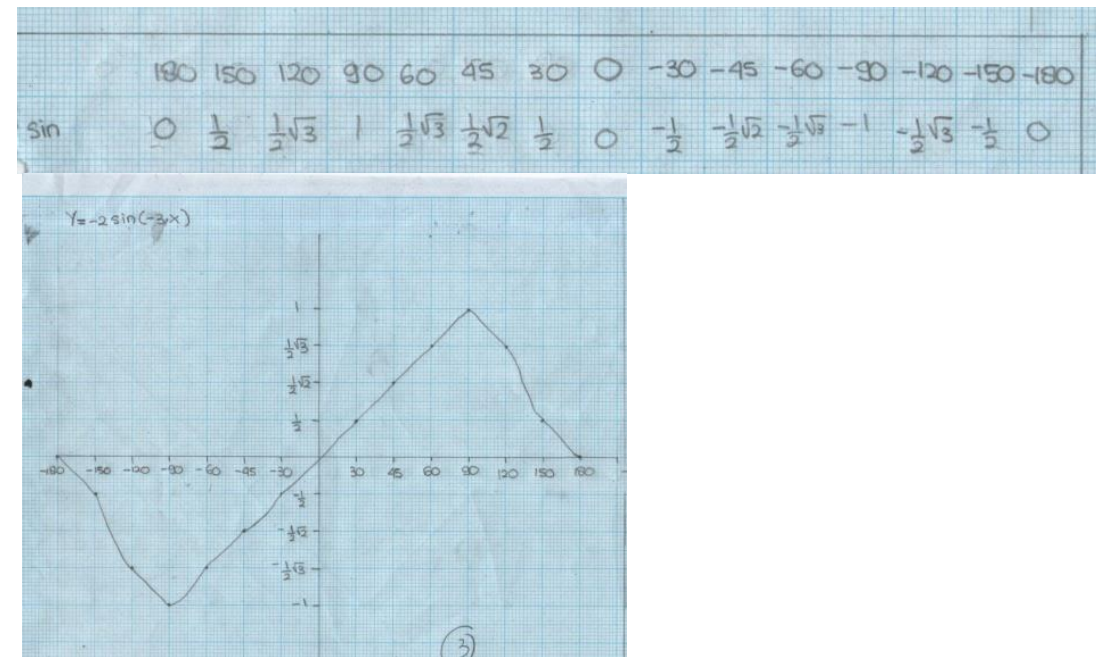

Figure 19. The result of the second indicator of the number 3

On the second indicator the subject is able to meet an indicator where the subject is able to redeclare the concept that has been studied, before drawing the subject graph write the Help table to draw the chart.

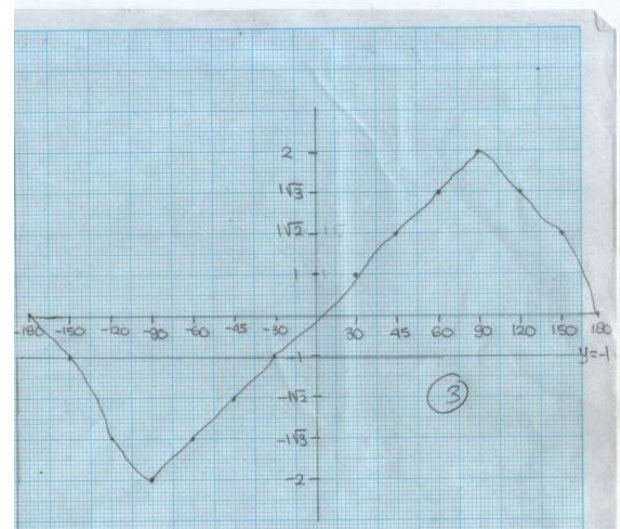

Figure 20. The result of work for the third indicator of the number 3

On the third indicator the subject is able to meet an indicator where the subject is able to classify the objects - objects based on the requirements that make up the concept, by sliding the $x$ axis as far as $y_{2}$ is known in the matter and the subject also Can find the cut point. 
$H p=\{-150,-30\}$ Nibimak simum: 2

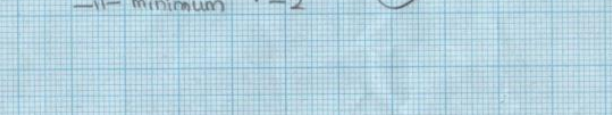

Figure 21. The result of work for the fourth indicator of the number 3

Based on the results and interviews, the subject is able to meet the indicator of understanding the fourth concept of being able to make conclusions based on concepts that have been studied, the subject is able to declare the value of completion The minimum questions asked in the question. When a subject interview session is also able to explain conclusions appropriately.

Understanding the concept with the category of being less capable of meeting the concept of understanding of concepts is only one indicator that almost all students with the category are able to fulfill the indicator redeclare the concept that has been studied. Students are able to create a first aid table before drawing graphs of trigonometric equations. When a student interview session can explain the results of the work correctly. This is in line with the research of Monalisa, Harman, Yarmayani (2019) that most students are only able to meet the indicators of restating concepts that have been studied. In this study some students actually understand the intent of the question but students are confused how to solve the problem. It is similar to the results of Pradana's research (2016) on understanding the concept of students still not fully embedded in the students, in fact students already understand the intent of the problem, but students have not mastered the counting operation on the material.

Based on the test results and interviews obtained from six students, the highest and lowest scores are 8 and 1 . The score gained can be categorized based on students ' critical thinking ability categories. The results of the study obtained from six students are four students with medium category and two students with low category for students ' critical thinking ability in solving trigonometric equations using graphs.

\begin{tabular}{|c|c|c|}
\hline$\overline{\text { Name }}$ & Skor & Category Critical Thinking \\
\hline $\mathrm{S} 1$ & 8 & Medium \\
\hline $\mathrm{S} 2$ & 7 & Medium \\
\hline S3 & 7 & Medium \\
\hline S4 & 7 & Medium \\
\hline S5 & 3 & Low \\
\hline S6 & 1 & Low \\
\hline
\end{tabular}

Thinking critically with medium categories, students are less capable of meeting critical thinking indicators in resolving trigometric equations using graphs. Students are less able to understand by writing down the answers to the problems given, less able to identify the relationship between problems with the concept given, less capable of using the appropriate strategy in the resolution of the given problem and Less able to draw conclusions correctly in resolving trigonometric equations using graphs. Thinking critically with low categories, students have not been able to meet critical thinking indicators in resolving trigometric equations using graphs. Students have not been able to understand by writing the answers of the problem given, not yet able to identify the 
relationship between problems with the concept given, not yet able to use the appropriate strategy in the problem solving given and yet Able to draw conclusions correctly in resolving trigonometric equations using graphs. The following is the result of several students with medium and low categories.

\section{1) Thinking Critical Students Category Medium}

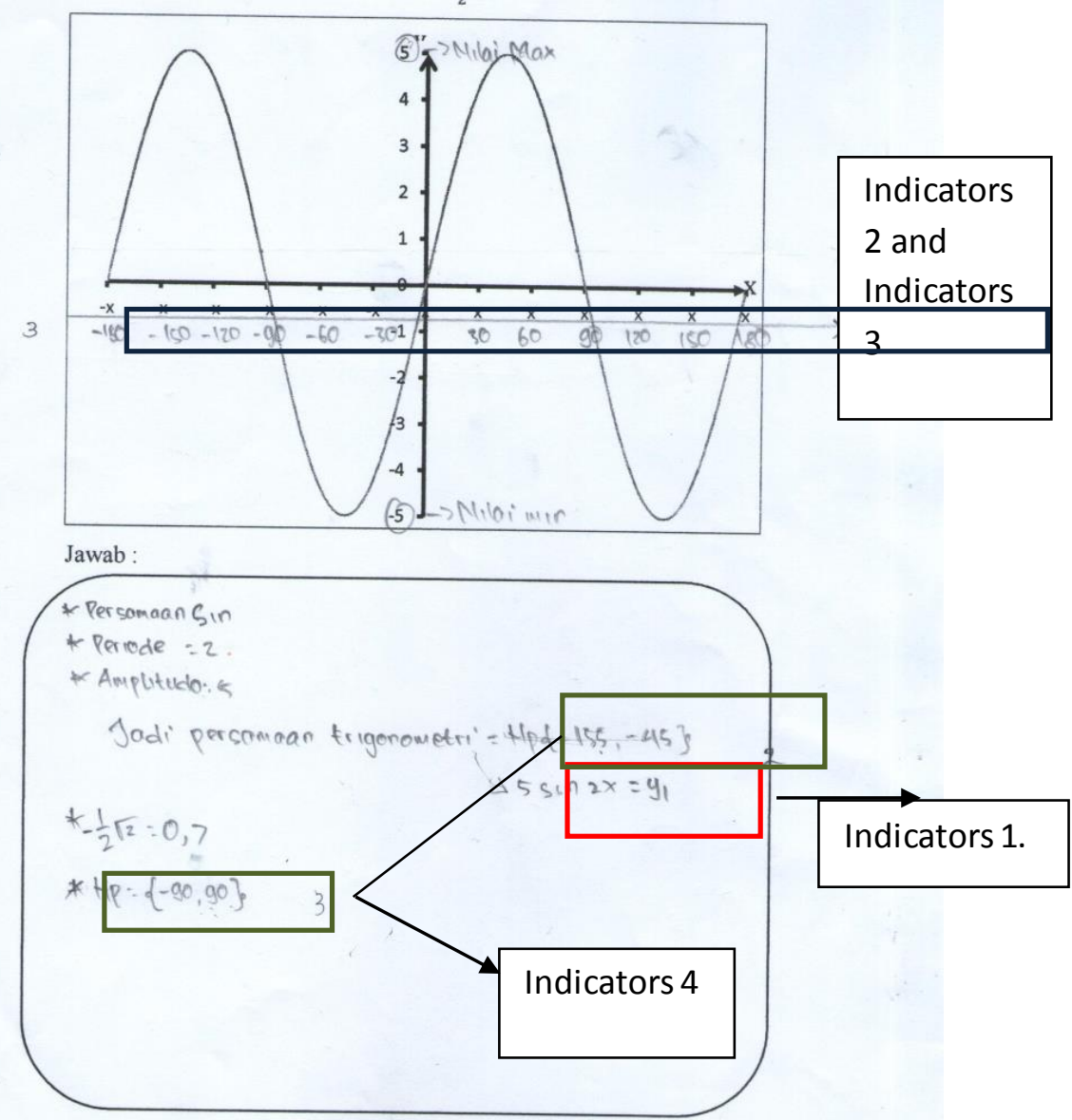

Figure22. The result of $S 1$ for number 4

In the first indicator, the subject has not been able to meet the interpretation indicators, i.e. understand the problem of trigonometric equations by writing down their trigonometry equations. The answer to question number 4 is supposed to be 2 equations that are equal to $y=5 \sin 2 x$ and $y=5 \cos (2 x-90)$. But the subject only renders 1 equation. During the interview session, the subject confessed that the subject found only one trigonomic equation of the image in question. That means the subject still has not been able to meet the first indicator of critical thinking ability in resolving trigonomic equations using graphs.

In the second indicator, the subject is able to meet the analytical indicators where the subject is able to identify the relationship between problems with the concept of trigonomic equations. In question number 4 The subject is asked to complete the $\mathrm{x}$ axis coordinates on the trigonometric chart. The subject is capable of answering it, and when the subject's interview session is also able to explain the value of the $\mathrm{x}$ axis coordinates are obtained from a special trigonometric angle.

On evaluation critical thinking indicators where the subject is less capable of using the appropriate strategy in solving trigonometric equations. The subject step in 
determining the completion of the Trigonometeri equation using the graph is correct, by sliding the $x$ line so far $y_{2}=-\frac{1}{2} \sqrt{2}$ or -0.7 . However, the subject is less capable in determining the point that cuts the $\mathrm{X}$ line and the $\mathrm{Y}$ line. In the work of the number 4 subject, writing two answers to the set of trigonometric equations. During the interview session, the subject admitted that the subject was still slightly confused, and forgot to remove the wrong settlement set.

Based on the results of the work and interviews, on the indicator of critical subject inference has not been able to draw conclusions correctly. Subjects have not been able to provide the reason for the subject's work on question number 4. During the interview session, the subject is still hesitant - doubtful about explaining the results. In the results of this research there are 4 students of medium category critical thinking ability and 2 students low category of critical thinking skills. This is in line with the research of the Kholifah (2017) that the average critical thinking ability of Class IX MTs. Annida AlIslamy based on the score of mathematical critical thinking ability is 63.3 this achievement is good (moderate).

2) Thinking Critical Students Category Low

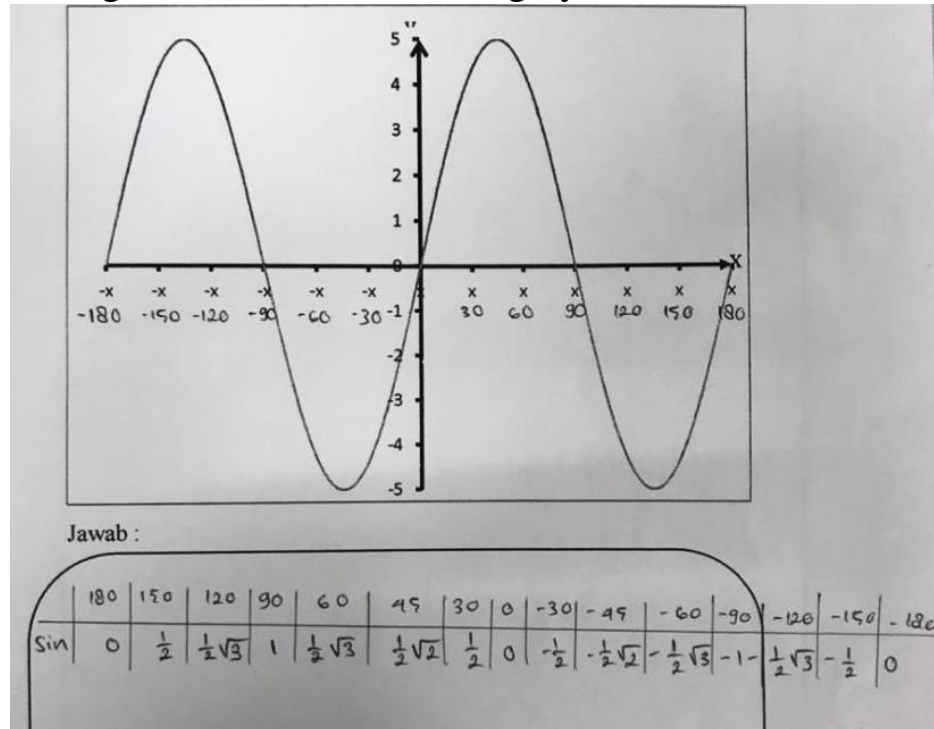

Figure 23. The results of the S5 work for number 4

At work answer number 4 The subject can only meet the critical thinking indicators of analysis alone, the subject is capable of complementing $\mathrm{x}$ axis coordinates only. The steps of the subject are also precise, making the table of the association first and then subtitling the value of the $\mathrm{x}$-axis coordinates. The subject of the Sapna still cannot write trigonometric equations, it is not able to determine the set of completion, and Have not been able to draw conclusions correctly by giving the right reasons. When the interview session, the subject is claiming to be true right can not determine trigonometric equations through pictures as in.

Based on the results of the tests and interviews, pointed out that in this study the critical thinking ability of students in Menyelesaiakan trigonometric equations using graphics is still not developed or no students have critical thinking ability High category. This is in line with the research of Fithriyah, Sa'dijah, \& Sisworo (2016) that students critical thinking ability is still low it is demonstrated with the test results that are not all done by the students. In addition, the research results from Nuryati, Diantoro, \& Zubaidah 
(2018) also showed that the students ' critical thinking ability low it proves that the students ' critical thinking skills still need further training in order to be improved.

\section{CONCLUSION}

Based on the results of the test and interviews to students, the ability level of understanding the concept of students in determining the set of trigonomic equations using graphs, obtained the subject of students understanding the concept with high and moderate levels. Students with a high level of understanding are able to fulfill all indicators - an indicator of concept comprehension. Students with the level of understanding of concepts are also meeting the indicators of understanding the concept but less appropriate, such as not being able to identify the properties of a concept. Students are also less able to classify objects based on the requirements that make up the concept of.

The level of students' critical thinking ability to determine the set of solving trigonomic equations using graphs obtained by the subject of students critical thinking moderate and low levels. Students with critical thinking levels are not yet able to meet interpretation indicators, i.e. students have not been able to understand and write the answer to the problem given. Students with critical thinking levels are also underprivileged to meet critical indicators of inference. Students with critical thinking levels are in the withdrawal of less capable conclusions, such as less capable of providing appropriate reasons for students ' workmanship. Students with critical thinking levels are low, not yet capable of meeting critical thinking indicators in determining the set solving trigonometric equations using graphs. Students have not been able to meet interpretation indicators, analytical indicators, evaluation indicators, and inference indicators. It is shown in student test results in solving trigonometric equations using graphs..

\section{REFERENCES}

Alamsyah, M. (2017). Analisis Kesulitan Pemahaman Konsep Matematika Dasar Pada Siswa Kelas VIII MTSN Balang-balang. Universitas Islam Negeri Alauddin Makassar.

Anistawati, Reza Dwi. (2016). Analisis Kemampuan Berpikir Kritis Siswa dalam Pemecahan Masalah Matematika Berdasarkan Langkah-langkah Polya. Skripsi S1 Pendidikan Matematika. Universitas Muhammadiyah Malang.

Fadzillah, N. (2016). Analisis Kesulitan Pemahaman Konsep Matematika Kelas VII SMP. Universitas Muhammadiyah Purworejo.

Fajar, Kodirun, S., \& Arapu. (2018). Analisis Kemampuan Pemahaman Konsep Matematis Siswa Kelas VIII SMP Negeri 17 Kendari. Pendidikan Matematika. Universitas Halu Oleo.

Fatmawati, H., Mardiyana, \& Triyanto. (2014). Analisis Berpikir Kritis Siswa dalam Pemecahan Masalah Matematika Berdasarkan Polya pada Pokok Bahasan Persamaan Kuadrat. Jurnal Elektronik Pembelajaran Matematika, 2(9), 899-910. https://doi.org/10.17605/OSF.IO/WSZA9

Fithriyah, I., Sa'dijah, C., \& Siswara. (2016). Analisis Kemampuan Berpikir Kritis Siswa Kelas IX-D SMPN 17 Malang. Prosiding Konferensi Nasional Penelitian Matematika Dan Pembelajarannya, (2502-6526), 580-590. https://doi.org/10.23971/eds.v5i2.732

Herawati, O. D. P., Siroj, R., \& Basir, D. (2010). Pengaruh Pembelajaran Problem Posing Terhadap Kemampuan Pemahaman Konsep Matematika Siswa Kelas Xi Ipa Sma Negeri 6 Palembang. Jurnal Pendidikan Matematika, 4(1), 70-80. https://doi.org/10.22342/jpm.4.1.312.

Huljannah, M., Sugita, G., \& Anggraini. (2015). Analisis Kesalahan Siswa dalam Menyelesaikan Soal Persamaan dan Identitas Trigonometri Berdasarkan Kriteria Watson di Kelas X SMA Al-Azhar Palu. Jurnal Pendidikan Matematika, 4(2), 164-176. 
Julaiha, S. (2011). Upaya Meningkatkan Pemahaman Konsep Trigonometri Siswa Kelas XMA AT-Tasyri' Tangerang Melallui Model Pembelajaran Kooperatif Metode Course Review Horay. Universitas Islam Negeri Syarif Hidayatullah.

Kholifah. (2017). Analisis Kemampuan Berfikir Kritis Matematis Pada Siswa SMP Kelas IX. Universitas Islam Negeri Syarif Hidayatullah.

Mahmuzah, R. (2015). Peningkatan Kemampuan Berpikir Kritis Matematik Siswa Smk Melalui Pendekatan Problem Posing. JURNAL E-DuMath, 4(1), 64-72. https://doi.org/10.26638/je.588.2064

Nuryati, L., Diantoro, M., \& Zubaidah, S. (2018). Analisis Kemampuan Berpikir Kritis Siswa SMP. Jurnal Penelitian Dan Pengembangan, 3(2), 155-158. https://doi.org/10.23971/eds.v5i2.732

Pradana, P. W. (2016). Analisis Kemampuan Pemahaman Konsep Pada MateriSistemPersamaan Linier Dua Variabel Berdasarkan Teori Apos Bagi Siswa Kelas VIII ESmp Negeri2 Getasan. Universitas Kristen Satya Wacana.

Rahayuningsih, S., \& Kristiawan, I. (2018). Kemampuan Berpikir Kritis Siswa Dalam Menyelesaikan Masalah Matematika. Conference on Innovation and Application of Science and Technology (CIASTECH 2018), (2622-1284), 245-253. Retrieved fromhttp://publishingwidyagama.ac.id/ejournal-v2/index.php/ciastech/article/download/629/581

Setyaningrum, V. F., Hendikawati, P., \& Nugroho, S. (2018). Peningkatan Pemahaman Konsep dan Kerja Sama Siswa Kelas X Melalui Model Discovery Learning. PRISMA, Prosiding Seminar Nasional Matematika, 1(1), 810-813.

Shanti, W. N., Sholihah, D. A., \& Martyanti, A. (2017). Meningkatkan Kemampuan Berpikir Kritis Melalui Problem Posing. LITERASI (Jurnal Ilmu Pendidikan), 8(1), 49-59. https://doi.org/10.21927/literasi.2017.8(1).48-58

Subroto, T., \& Sholihah, W. (2018). Analisis Hambatan Belajar pada Materi Trigonometridalam Kemampuan Pemahaman Matematis Siswa.

Turmuzi, M. (2017). Meningkatkan Kemampuan Berpikir Kritis Pada Perkuliahan Geometri Bilangan Kompleks Dengan Discovery learning Dipadukan Dengan Cooperative Learning Tipe NHT (Numbered Head Together). Prosiding Seminar ELPSA, 1(1), 57-67. 